\title{
Optimization of The Village Roles in Countermeasure to Criminal Acts of Human Trafficking
}

\author{
Erma Rusdiana, Eny Suastuti, and Syamsul Fatoni ${ }^{1 *}$ \\ ${ }^{1}$ Lecturer of Law Department, University of Trunojoyo Madura
}

\begin{abstract}
This research is based on the criminal acts of human trafficking phenomenon through the Indonesian migrant workers delivery initially impersonating the recruitment activities by the scalpers in the village level in number of ways. The evidences show the poor village authorities regarding the issue at hand and relating to its people working abroad. This research aims to analyze Law No 18 of 2017 mandating the village government to actively participate in protecting the Indonesian especially the criminal acts of human trafficking cases. This is doctrinal legal research; employing the law approach in the sense of law in the book applying the statute approach. This research demonstrates the argument of Law No. 18 of 2017 legalization which is to provide the village authorization setting to extend migrant workers protection before, during, and after completion of their work. To implement the Article 42 pertaining to village's duties and responsibilities, its government can arrange the village regulation about PMI. It is clearly stated in Law No 6 of 2014 about Village. It is subsequently beneficial in a way that the village, as the main key of worker distribution, actively participates in criminal acts of human trafficking anticipation impersonating the Indonesian migrant workers delivery and simultaneously provides the Indonesian migrant workers protection.
\end{abstract}

\section{Introduction and literature review}

The development goal of a country is to increase the community welfare. However, in the process of such equitable development implementation, many marginal people are still found. It illustrates a large number of people are not yet benefited from the development outcomes living in poverty with limited employment opportunities. [1]

The science and technology developments facilitate the human traffic. It brings both positive and negative effect in the form of the emergence of various criminal acts including

\footnotetext{
Corresponding author : erma.rusdiana@trunojoyo.ac.id
} 
the human trafficking. One of the modus operandi is to delivery and placement of Indonesia migrant workers. It can be seen from the scope, characteristics, and modus operandi of the perpetrators, this can be considered as the organized crime.

Working is a basic human right that must be respected, esteemed, and guaranteed as mandated inUUD1945. The State obliges to guarantee rights, opportunities, and provides a shield cover for every citizen without discrimination to job opportunities and a decent income, both inside and outside of the country with the expertise, skills, talents, interests, and abilities. Therefore, Indonesian migrant workersmust be protected from human trafficking, slavery and forced labour, victims of violence, arbitrariness, a crime against the dignity and human rights, as well as other treatment violating human rights. [2]

The good side of human traffic is that it is able to resolve unemployment problems in the country and improve the welfare of society, while the downsides are the inevitable inhumane treatments against Indonesian migrant workers. These labors might have risks even before, during or after work or when returning to Indonesia especially whenthey do not follow the official procedure, it can be positioning them into worst conditions. The indication of high criminal acts of human trafficking can be seen from the data collected by the Indonesian Crisis Centre through the complaint system, which has received reports from the 4,761 migrant workers in some countries, including 56 confirmed cases of human trafficking, and 1,928 cases are indicatedas human trafficking. [3]

Villages as the first departure of Indonesian migrant workersare expected to play a role in tackling the crime. The problems have actually arisen within the village as the unofficial middlemen repeatedly persuade local residents to work abroadwith any ways;data falsification of documents including IDs, Birth Certificates, and Passports. In addition, the officials are excluded in the recruitment process often leading them to be unable to keep track of all the data of the citizens working abroad.

Toprotect Indonesian migrant workers, Government has stipulated the Law No 18 of 2017 about the protection against Indonesian migrant workers. In its consideration, it is stated that the placement and protection of Indonesian migrant workersshould be integrated among government agencies, both central and regionalby involving all communities.[3] This law concerns on the regulation of the Indonesian migrant workersprotection which shouldbe held by the central and regional Government, starting before, during and after working. Private parties's role is to manage the placement of Indonesian migrant workers. As for the protections for the Indonesian prospective migrant workersand the Indonesian migrant workers are: [4]

a. Ensure the fulfillment and enforcement of human rights as an Indonesian citizen and Indonesian migrant workers; and

b. Ensure the legal, economic, and social protection of Indonesian migrant workers and their families.

The state's commitment to provide protection and respect to human rights of Indonesian migrant workersis demonstrated in the enforcement of the State's role in both central and regional levels. The State'sinvolvement in this issue will minimize the exploitative actions conducted by private parties for highest possible profit purposes. [5] Several articles in Law No 18 of 2017 clearly divides the Central, the regional of the province, the city and villagegovernments' roles, from Article 39 to 42.

\section{Objective of the study}

This study is not only bound to the criminal issues and condemnations, but also the background triggering such criminal acts, based on observations on some types of crime such as trafficking with delivery and placement of Indonesian migrant workers modes.The 
occurrence of crimes as the root of the problem thus became a factor which impedes tackling the crime. Considering that villages are the strategic position as the first stage of Indonesian migrant workers recruitment, they should be able to carry out the tasks and duties mandated by article 42 of Act No. 18 of 2017. Therefore, it is crucial to examine the optimization of the role of the village in an effort to combat trafficking acts in law No.18Year 2017.

\section{Discussion}

\subsection{Prevention Human Trafficking from The Perspective of Law No. 17 of 2018}

Preventions mean the power of all the efforts made by any person or Government agencies or private entities aimed at security, mastery and life prosperity by complying with the existing human rights principles. [6] The effort or policy to countermeasure crimes cover the criminal policy field. This is inseparable from a broader one, namely social policy encompassing policies to increase social welfare and defendthe society. The crime prevention policy is done by using the means of criminal law, then the policy of the criminal law in particular on judicial policy should emphasize and lead to the achievement of the objectives namely social welfare and social defence.[6] Generally, the crime prevention efforts refer to two points:penal (criminal law) and non-penal(outside of the criminal law).

To overcome criminal acts committed mostly in the placement of the Indonesian migrant workers and to provide better protection towards them, the decentralization of Indonesian migrant workersservice is set in the Act No. 18 of 2017 about the Indonesian migrant workersprotection is crucial. Although the era of decentralization and regional autonomy have implemented, the evidence remains centralistic still. The local government has not significantly involved in the protection mechanism of Indonesian migrant workers. Law No. 17 of 2017 demonstrates one-stop integrated services at the provincial, regency, even the village level. Therefore, the local governmentparticipation must be takenin Indonesian migrant workersprotection. [7]

The criminal act of human trafficking is normally initiated with the placement method not complying with the procedures and violates the regulations Indonesian migrant workersplacement. The private recruitment agency (PPTKIS)startstheir activity in the village where the prospective Indonesian migrant workersare taken from. So far, the candidates are recruited directly from their houses, transferred to a big city and accommodated in shelters thentransported abroad without any documents orrecords from the village. There are three stages of the potential occurrence of how the act of human trafficking frequently take place i.e. a) pre-working including the recruitment process, b) the transportationand placement of Indonesian migrant workersand c) the exploitation stage.[8]

Law No.18 of 2017 explicitly specifies the criminalization of some activities of the Indonesian Migran Workersplacement associating with criminal acts of human trafficking;

1. Article 66: Individuals are prohibited from placing Indonesian Migran Workerswith no age requirements;

2. Article 67:Individuals are prohibited from placing Indonesian migrant workerscandidates at a) the position and the type of work different from the working contract harming the candidates as stipulated in Article 19 paragraph (2); or b) work but against the legislation;

3. Article 68: Individuals are prohibited from carrying out the placement that does not meet Indonesian migrant workersrequirement;

4. Article 69: Iindividuals are prohibited from carrying out the placement of the Indonesian migrant workers 
5. Article 70: a) Any officials areprohibited to send out Indonesian migrant workerswith below requirement standard of the documentcompleteness referred in Article 13 and place the Indonesian migrant workerson work against the contract agreed upon and signed by Indonesian migrant workers; b) put the Indonesian migrant workerson work against the expertise, skills, talents, interests, and abilities; c) divert or hand over SIP3MI to other parties;

Criminal acts in the placement Indonesian migrant workersin Law No. 18 of 2017 are qualified as crimes with the threat of a maximum imprisonment of 10 Years and or a fine of at most 15,000,000,000 (fifteen billion) as regulated from Article 79 to 86. Corporations are threatened with a principal penalty, i.e. a criminal fine with the maximum criminal provision plus $1 / 3$ (one third) of each criminal penalty. Furthermore, corporations can be subject to additional penalties in the form of license revocation.

\subsection{The role of the village in Combating the Human Trafficking Crime}

As to protectIndonesian migrant workers, the village has important responsibilities as set forth in Article 42, Law 18 of 2017: receiving and providing information as well as requesting work from institutions conducting the state affairs in the field of employment; verifying data and recording Indonesian migrant workerscandidates; facilitating the administration requirement; monitoring the departure and return of Indonesian migrant workers; and empowering prospective Indonesian migrant workersand their families.

The above regulation is very important as the legal umbrella for the village to perform a wider range of activities regarding the Indonesian migrant workersrecruitment and placement. Through this setting, villages can formulate a set of policies in order to provide protection for its communities before, during and after working.

Regarding the village's authority in making regulations in 1945 Constitution and various legislative provisions in Indonesia, it has been stipulated that the legal authority to make and determine a legal product is carried out by the executive and legislative institutions, from the central up to the district and city levels, including the village level.[9] With the autonomy, villages have the authority to regulate themselves and make regulations. Village regulations are initiated and issued by the government and communities in order to manage the development and implementation of village governance for community benefits. Village regulations are important for village development.[10]Law No. 6 of 2014 concerning about Villages provides broader authority. Therefore, in terms of regulating the community interest and providing economic prosperity to people, the village government can make regulations at lower level. In order to provide the best service and overcome the crime of human trafficking with the mode of sending and placing Indonesian migrant workers, the village government can establish village regulations which particularly emphasize the Indonesian migrant workerssafe migration and protection and their family members. Regarding to the type, preparation of the mechanism of the village regulation is regulated in the provisions of article 69 of the Village Law.

The material of village regulations has been regulated in the Minister of Home Affairs Regulation Number 29 of 2006 pertaining to Formation Guidelines and Mechanisms for drafting the Village Regulations in Article 4 Paragraph (1) stipulating that the charge material is the whole material to support the organization of village government, construction of the village, and empowerment of the community, as well as further elaboration of the higher legislation.[12] In essence, its formulationis not carried out solely to fulfil the tasks of the village head and BPD, but to resolve problems and provide benefits to villagers. The village regulation, as one of the legal instrument governing the community, must have the authority to gain respect from the community. [12] 
By adhering some rules mentioned above, to protect the citizens from trafficking in persons, village government can take the initiative to form the regulation. This is one of the first preventive efforts in tackling crimes to minimize the occurrence of crime. It is fullyapprehensible when preventive efforts should be prioritized done by anyone without special expertise and disadvantaged economic. Through its regulation, this preventive action can be fully carried out by the village and its community.

In village regulation creation process, however,numerous challenges come from structural and functional institutionsor by village regulations procedure and process. They are:[12]

a. The established system in drafting village regulations hasnot been yet to provide spacious, secure, and adequate rooms for community participation.

b. There has not been any political awarenessfrom the village government (as the process prerequisite participation) to involve the community in the process of preparing the role of the village.

c. There has been a flourishing culture of an absence in participation so the participation often seen as resistance expression.

d. The community has a low capacity to participate.

e. The financial problems as in the implementation of participation could not be separated from funding.

Furthermore, participation requires human resources quality because the community participation is substantial.Without active community participation, the space open cannot beutilized to the fullest. Amitai Etzioni (1968) defines active community as whose can determine them selves and commit and access to the information.

\section{Conclusion}

Law No. 18 of 2017 about protectionof Indonesian Migran Workers,Law No. 17 of 2017,Law No. 6 of 2014 about broader village authorization, in terms of regulating the interests of the local community as well as to provide economic prosperity. In line with Law No. 6 of 2014and Law No. 18 of 2017, one important thing to set is the decentralized services of Indonesian migrant workers, as well as presenting one-stop integrated services at the provincial and regency levels, even the village. Further,Law No. 18 of 2017 explicitlyregulates the duties and responsibilities of a village, in section 42 of Law No. 18 of 2017. Through the regulations, the village can formulate a range of policies in order to provide protection for its citizens starting before, during and after working as Indonesian migrant workers. With the existence of autonomy, a village has the authority to make village policies and the village government can make the irregulations. For this reason,Village Government can arrange the lower level of village regulations specifically set on safe migration and protection against Indonesian migrant workers and their family members. Those are preventive efforts to combat criminal acts of trafficking in persons.

\section{References}

1. N. M. S.Hutapea, Penanggulangan Tindak Pidana Perdagangan Orang, summary of Dissertation, Accessed at: www.usi.ac.id/karya ilmiahdosen.

2. Reviewing Act Number18year 2017 about the protection of Indonesian MigrantWorkers.

3. Embassies And Consulates USA in Indonesia, Laporan Tahunan Perdagangan Orang 2017 Accessed at: https://id.usembassy.gov/id/laporan-tahunan-perdagangan-orang2017/. (2017).

4. Act Number No. 18 Tahu 2018 about The Protection of Indonesian Migrant Workers. 
5. E. Ratnaningsih, Paradigma Baru Pekerja Migrant, Accessed at: http://businesslaw.binus.ac.id/2017/12/31/paradigma-baru-perlindungan-pekerja-migran-indonesia/. (2017).

6. B. N.Arief, Masalah Penegakan Hukumdan kebijakan HukumPidana Dalam Penanggulangan Kejahatan ( Kencana, jakarta, 2007).

7. S. E.Hardum, Pemerintah Sedang Susun Peraturan Turunan UU TKI yang Baru, Accessed at: http://www.beritasatu.com/ekonomi/499066-pemerintah-sedang-susunperaturan turunan-uu-tki-yang-baru.html. (2018)

8. J. Ester, Tindak Pidana Perdagangan Orang dalam perspektif Tindak Pidana Transnasional yang Terorganisasi, Dissertation, (Program Doktor Program Studi Ilmu Hukum, Fakultas Hukum Universitas Airlangga, Surabaya, 2013).

9. TAP MPR No V/MPR/2000 Pemantapan Persatuan dan Kesatuan Nasional.

10. F. P. Gara, Efektifitas Fungsi Pemerintah Desa Dalam Pembuatan Peraturan Desa di Desa Wori (Studi Kasus di Desa Wori Kecamatan Wori kabupaten Minahasa Utara),Jurnal Eksekutif1, 7 (2016).

11. N.K. Rumokoy, Prinsip-prinsip Pembentukan Peraturan Kepala Desa berdasarkan Undang-undang Nomor 12 tahun 2011, Jurnal Hukum Unsrat21, 3, Pg 1 - 11 (2013).

12. Mekanisme Pembuatan Perturan Desa, Summarized and quoted from R. SeptyartoPriandono's paper (Designers of legislation in the Regional Office of the Ministry of Law and Human RightsDIY). Accessed at: http://www.keuangandesa.com/2015/03/mekanisme-pembuatan-peraturan-desa (2015) 